Б. М. Урбагарова, Л. Д. Раднаева, В. В. Тараскин. Компонентный состав эфирного масла Saposhnikova divaricata (turcz.) schischk. Корней

УДК: 615.322

DOI: 10.18101/2306-1995-2019-3-49-55

\title{
КОМПОНЕНТНЫЙ СОСТАВ ЭФИРНОГО МАСЛА SAPOSHNIKOVADIVARICATA (TURCZ.) SCHISCHK. КOPHEЙ
}

(C) Урбагарова Баярма Мунхоевна

преподаватель кафедры фармации,

Бурятский государственный университет им. Д. Банзарова

Россия, 670002, г. Улан-Удэ, ул. Октябрьская, 36а

тел: 8(3012)44-55-03

E-mail: urbagarova.bayarma@mail.ru

кандидат биологических наук,

старший научный сотрудник лаборатории химии природных систем

Байкальский институт природопользования СО РАН,

Россия, 670047, г. Улан-Удэ, ул. Сахьяновой, 6

тел.: (3012) 43-36-76

E-mail: zhig2@yandex.ru

(C) Раднаева Лариса Доржиевна

доктор химических наук, профессор,

заведующая лабораторией,

Байкальский институт природопользования СО РАН

Россия, 670047, г. Улан-Удэ, ул. Сахьяновой, 8

тел.: (3012) 43-49-97

заведующая кафедрой фармации,

Бурятский государственный университет им. Д. Банзарова

Россия, 670002, г. Улан-Удэ, ул. Октябрьская, 36а

тел: 8(3012) 44-55-03

E-mail: radld@mail.ru

\section{(C) Тараскин Василий Владимирович}

кандидат фармацевтических наук,

старший научный сотрудник лаборатории химии природных систем, Байкальский институт природопользования СО РАН

Россия, 670047, г. Улан-Удэ, ул. Сахьяновой, 6

старший преподаватель кафедры фармации медицинского института,

Бурятский государственный университет им. Д. Банзарова

Россия, 670002, г. Улан-Удэ, ул. Октябрьская, 36а

тел: 8(3012)44-55-03

E-mail: vvtaraskin@mail.ru

Эфирные масла получены методом перегонки с водяным паром по методу I. Методом газо-хромато-масс-спектрометрии изучен химический состав данной группы вторичных метаболитов сапожниковии растопыренной корней флоры России и Монголии. В эфирном масле Saposhnikoviadivaricata (Turcz.) Schischk. флоры Китая обнаружены неспецифические компоненты, что указывает на наличие примесей. 
Ключевые слова: Saposhnikoviadivaricata (Turcz.) Schischk.; Apiaceae; эфирные масла; $\beta$-бисаболен; (Z)-фалькаринол; FangFeng; лекарственное растительное средство; лекарственное растительное сырье.

Для цитирования

Урбагарова Б. М., Раднаева Л. Д., Тараскин В. В. Компонентный состав эфирного масла Saposhnikova divaricata (turcz.) schischk. Корней // Вестник Бурятского государственного университета. Медицина и фармация. 2019. Вып. 3. С. 49-55.

Сапожниковия растопыренная (Saposhnikoviadivaricata (Turcz.) Schischk.) представитель семейства Зонтичные (Umbelliferae), или Сельдерейные (Apiaceae). На протяжении нескольких тысячелетий корни данного растения широко применяются в традиционной медицине Китая, Японии и Кореи. Так, первое письменное упоминание наблюдается в трактате по лекарственным растениям «Shen Nong Ben Caо Jing», составленном при династии Цинь-хан [1], согласно которой Fang Feng (Saposhnikovia divaricata (Turcz.) Schischkin) относится к высшему классу лекарственного растительного сырья по фармакологическому действию. Позже в китайском медицинском трактате «Materia Medica» («Ben Caо Hui Yan»), написанном при династии Мин, описывается практическое применение сапожниковии растопыренной корней для лечения артрита, артралгии, головных болей, при атрофии и вялости мышц, лихорадке, заложенности носа, цереброваскулярных заболеваниях, на начальных стадиях оспы и тревоги у детей [2]. В настоящее время в традиционной китайской медицине корни данного растения применяются в виде отвара с жаропонижающим действием, этанольного экстракта с противовоспалительным и противопростудным эффектами [3, 4]. Известен ряд лекарственных средств, содержащих сапожниковии растопыренной корни: Shen Nung Pen Tsao Ching анальгезирующее средство, Chuanxiong Chatiao - противопаркинсонический многокомпонентный сбор, Tong-Xie-Yao-Fang - сбор, применяющийся при синдроме раздраженного кишечника, и другие $[5,6,7,8,9,10]$. Высокая биологическая активность объясняется богатым химическим составом растения, так, по данным литературы известно, что сапожниковии растопыренной корни содержат хромоны, кумарины, полиацетиленовые соединения, жирные кислоты, эфирные масла, флавоноиды, дубильные вещества, азотсодержащие соединения [11]. Известно, что эфирные масла сапожниковии растопыренной корней обладают жаропонижающим, болеутоляющим и противовоспалительным действиями [12]. Компонентный состав эфирного масла сапожниковии растопыренной корней флоры России и Монголии ранее не изучался.

Таким образом, целью исследования явилось изучение химического состава эфирного масла Saposhnikoviae divaricataer adices.

Объектами исследования явились сапожниковии растопыренной корни, собранные на территории Тарбагатайского, Иволгинского, Мухоршибирского районов Республики Бурятия, Агинского и Кыринского районов Забайкальского края Российской Федерации, Хэнтэйского аймака Монголии, а также в качестве одного из объектов выступили Saposhnikoviaedivaricataeradices, приобретенные в аптечном учреждении г. Синин провинции Цинхай Китая. 
Б. М. Урбагарова, Л. Д. Раднаева, В. В. Тараскин. Компонентный состав эфирного масла Saposhnikova divaricata (turcz.) schischk. Корней

Эфирное масло выделяли методом перегонки с водяным паром (метод I) согласно требованиям ОФС 1.5.3.0010.15 [13]. Компонентный состав эфирных масел исследовали на газовом хроматографе Agilent 6890 с квадрупольным массспектрометром (MSD 5973N) в качестве детектора. Использовалась 30-метровая кварцевая колонка HР-5ms с внутренним диаметром 0.25 мм, толщиной плёнки $0.25 \mu$ м (сополимер 5\%, дифенил 95\%, диметилсилоксан), газ-носитель - гелий $\left(1.0\right.$ мл/мин); температура $\left({ }^{0} \mathrm{C}\right)$ : испарителя -280 , колонки - 50 (2 мин), 50-200 (40 $\mathrm{C} /$ мин), 200-280 ( $20^{\circ} \mathrm{C} /$ мин), 280 (изотерма 5 мин), источника ионов - 170, интерфейса между газовым хроматографом и масс-селективным детектором - 280. Энергия ионизирующих электронов - 70эВ. Объём пробы 1 мкл раствора с разделением потока 60:1. Качественный анализ основан на сравнении времен удерживания и полных масс-спектров соответствующих чистых соединений библиотеки хромато-масс-спектрометрических данных летучих веществ растительного происхождения с полученными данными. Процентное содержание компонентов эфирных масел вычисляли по площадям газо-хроматографических пиков без корректирующих коэффициентов.

Полученные эфирные масла представляли собой легкоподвижную эссенцию ярко-оранжевого цвета с приятным бальзамическим запахом, выход которых во всех 11 образцах составил $0.22-0.35 \%$ в пересчете на а.с.с. При исследовании химического состава эфирного масла выявлено наличие лишь двух компонентов: $\beta$-бисаболен, (Z)-фалькаринол (панаксинол) (рис. 1).

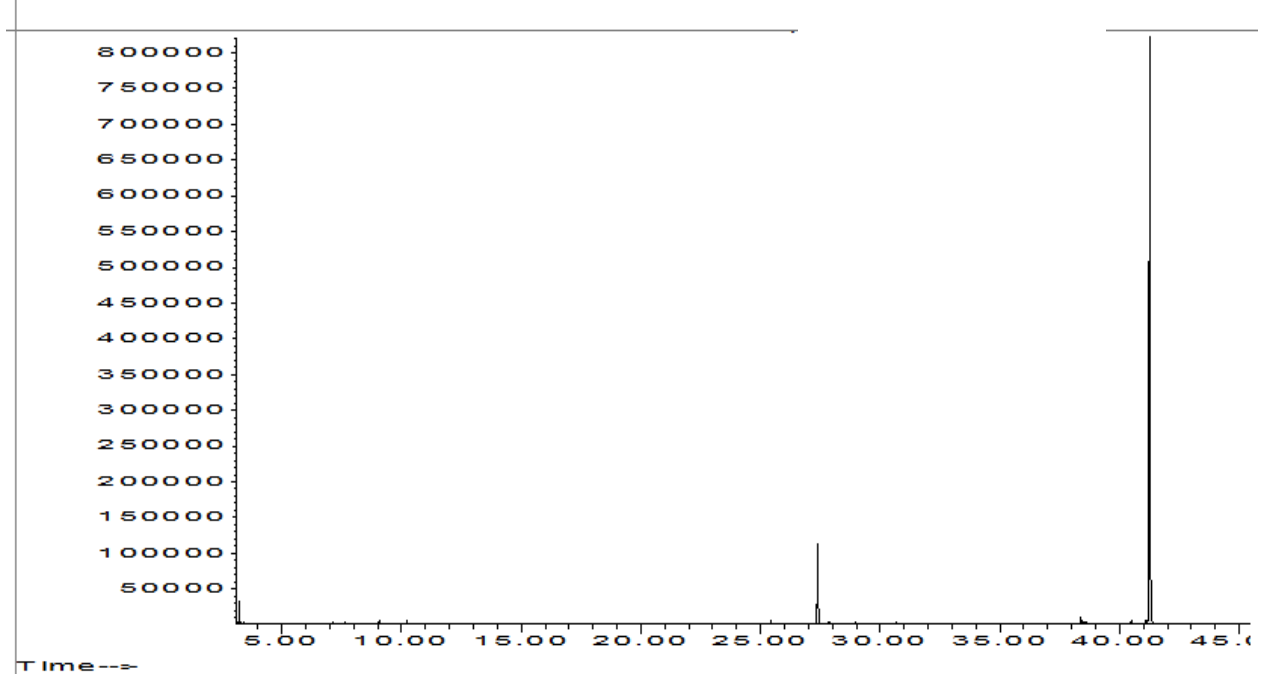

Рис. 1. Хроматограмма эфирного масла, выделенного из корней сапожниковии растопыренной, собранных в окрестностях с. Тарбагатай

Тарбагатайского района Республики Бурятия в 2015 г.

Содержание моноциклического сесквитерпеноида $\beta$-бисаболен составило 1.81-100.00\%, полиацетиленового соединения (Z)-фалькаринол - 21.67-98.19\% от суммы компонентов (табл. 1). 
Компонентный состав эфирного масла Saposhnikoviaedivaricataeradices

\begin{tabular}{|c|c|c|c|}
\hline № & Место сбора образца & $\begin{array}{c}\beta- \\
\text { бисаболен, \% }\end{array}$ & $\begin{array}{c}\text { (Z)- } \\
\text { фалькаринол, \% }\end{array}$ \\
\hline 1 & $\begin{array}{l}\text { Россия, Республика Бурятия, } \\
\text { Тарбагатайский район, } \\
\text { с. Тарбагатай, } 2015\end{array}$ & 10.22 & 89.78 \\
\hline 2 & $\begin{array}{l}\text { Россия, Республика Бурятия, } \\
\text { Тарбагатайский район, } \\
\text { с. Тарбагатай, } 2018\end{array}$ & 7.30 & 92.70 \\
\hline 3 & $\begin{array}{l}\text { Россия, Республика Бурятия, } \\
\text { Иволгинский район, } \\
\text { с. Колобкки, } 2018 \\
\end{array}$ & 1.81 & 98.19 \\
\hline 4 & $\begin{array}{l}\text { Россия, Республика Бурятия, } \\
\text { Иволгинский район, } \\
\text { пос. Иволгинск, } 2018\end{array}$ & 6.37 & 93.63 \\
\hline 5 & $\begin{array}{l}\text { Россия, Республика Бурятия, } \\
\text { Мухоршибирский район, } \\
\text { с. Гашей, } 2015\end{array}$ & 3.21 & 96.79 \\
\hline 6 & $\begin{array}{l}\text { Россия, Забайкальский край, } \\
\text { Кыринский район, } \\
\text { с. Тарбальджей, } 2014\end{array}$ & 100.00 & - \\
\hline 7 & $\begin{array}{l}\text { Россия, Забайкальский край, } \\
\text { Агинский район, с. Лаха, } 2014\end{array}$ & 28.62 & 71.38 \\
\hline 8 & $\begin{array}{l}\text { Монголия, Хэнтэйский аймак, } \\
\text { местность Бэрх, } 2014\end{array}$ & 12.64 & 87.36 \\
\hline 9 & $\begin{array}{l}\text { Монголия, Хэнтэйский аймак, } \\
\text { местность Бэрх, } 2015\end{array}$ & 4.24 & 95.76 \\
\hline 10 & $\begin{array}{l}\text { Монголия, Хэнтэйский аймак, } \\
\text { местность Баян Уул, } 2015\end{array}$ & 3.14 & 96.86 \\
\hline 11 & $\begin{array}{l}\text { Китай, аптечное сырье } \\
\text { приобретено в г. Синин, } 2015\end{array}$ & 1.89 & 21.67 \\
\hline
\end{tabular}

Внимание привлекло эфирное масло из образца китайского происхождения, которое в большом количестве содержало простой алкилфталид - (Z)лигустилид (73.29\%) (рис. 2). 


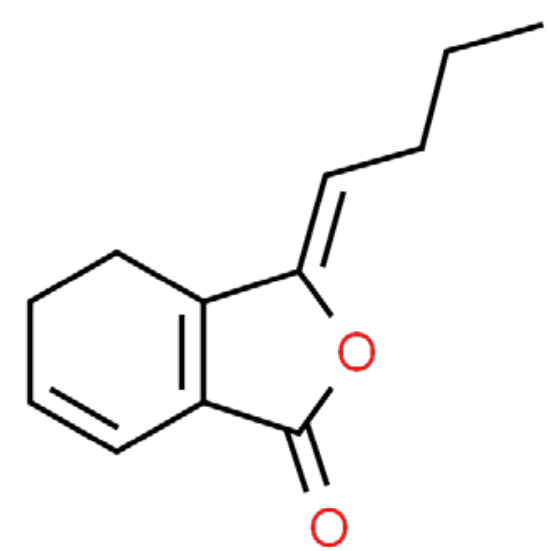

Рис. 2. Структурная формула (Z)-лигустилида

Данный компонент можно считать специфическим маркером эфирных масел дудника китайского (Angelica sinensis (Oliv.) Diels.) и дудника остролопастного (Angelicaacutiloba (Siebold\&Zucc.) Kitag.), корни которых применяются при нарушении менструального цикла, гипотонусе матки $[14,15]$. Одновременное содержание лигустилида и фалькаринола в эфирном масле китайского образца, с одной стороны, свидетельствует о наличии корней дудника, а с другой сапожниковии растопыренной. Более достоверным фактом присутствия корней сапожниковии растопыренной является наличие хромонов (перв-Oглюкозилцимифугина и 4'-O- $\beta$-D-глюкозил-5-O-метилвисамминола) в данном растительном материале [16]. Результаты анализа компонентного состава эфирных масел Saposhnikoviaedivaricataeradices флоры Китая указывают на наличие примесей. Стоит отметить, что при применении Angelica sinensis radices имеются противопоказания, такие как детский возраст, геморрагические заболевания, гиперменорея, беременность и период лактации.

Таким образом, впервые изучен компонентный состав эфирных масел, выделенных из сапожниковии растопыренной корней (Saposhnikoviaedivaricataeradices) флоры Республики Бурятия и Забайкальского края Российской Федерации и Хэнтэйского аймака Монголии. Эфирное масло корней богато моноциклическим сесквитерпеновым углеводородом - $\beta$ бисаболеном и полиацетиленовым соединением - (Z)-фалькаринолом (панаксинолом). В лекарственном растительном сырье китайского происхождения выявлено наличие примесей дудника китайского корней.

Лuтература

1. The Divine Farmer's Materia Medica (A translation of the Shen Nong Ben Cao Jing by Yang Shou-zhong) // Blue Poppy Press. 2008. 214 p.

2. Ni, Zh. Materia Medica Words (Chinese Edition). Beijing: Beijing TCM Ancient Books Publishing House, 2005. 783 p.

3. Kreiner, J. Saposhnikoviae divaricata: a phytochemical, pharmacological, and pharmacokinetic review / J. Kreiner, E. Pang, G.B. Lenon, A.W.H. Yang // Chinese Journal of Natural Medicines. 2017. Vol. 15 (4). P. 255-264.

4. The Chinese Pharmacopoeia / Chinese Pharmacopoeia Commission. 2015. 
5. Ip, S-P. Quality assurance for Chinese herbal formulae: standardization of IBS-20, a 20-herb preparation / S-P. Ip, M. Zhao, Y. Xian, M. Chen, Y. Zong, Y-W. Tjong // Chinese Medicine. 2010. Vol. 5. P. 8.

6. Li, X-zh. Recent advances in herbal medicines treating Parkinson's disease / X-zh. Li, Sh-n. Zhang, S-m Liu, F. Lu // Fitoterapia. 2013. Vol. 84. P. 273-285.

7. Metabolic profiling of the traditional Chinese medicine formulationYu Ping Feng San for the identification of constituents relevant foreffects on expression of TNF- $\alpha$, IFN- $\gamma$, IL-1 $\beta$ and IL-4 in U937 cells / N. Stefanie, M. Marlene, Z. Huiqin, L. Yong, H. Xiaojuan, F. Danping, L. Aiping, Y. Kate, I. Giorgis, B. Rudolf // Journal of Pharmaceutical and Biomedical Analysis. 2017. Vol. 145. P. 219-229.

8. The effect of Da-Fang-Feng-Tang on treatment of type II collagen-induced arthritis in DBA/1 mice / L.R. Wang, N. Ishiguro, E. Yamada, Y. Nishida, K. Sato, H. Iwata // American Journal of Chinese Medicine. 1991. Vol. 27 (2). P. 205-215.

9. HPLC-MS and HPLC-MS/MS analysis of seven active constituents of Xiao-XuMing decoction and application to a pharmacokinetic study after oral administration to rat / Y. Wang, Ch. Ding, C. Wu, K. Du, J. Zhang, H. Qin, J. Hou, G. Du // Acta Pharmaceutica Sinica B. 2012. Vol. 2 (2). P. 188-197.

10. Qualitative and quantitative analysis of chemical constituents in traditional Chinese medicinal formula Tong-Xie-Yao-Fang by high-performance liquid chromatography/diode array detection/electrospray ionization tandem mass spectrometry / Zh. Yan, X. Yang, J. Wu, H. Su, Ch. Chen, Y. Chen // Analytica Chimica Acta. 2011. Vol. 691. P. 110-118.

11. Растительные ресурсы России. Дикорастущие цветковые растения, их компонентный состав и биологическая активность. Т. 3. Семейства Fabaceae-Арiaceae / отв. ред. А. Л. Буданцев. СПб.; М.: Товарищество научных изданий КМК, 2010. 601 с.

12. Shen, Y.J. Relieving prescription of traditional Chinese medicine. M. Beijing: Chinese Medical Press, 2005. P. 196-197.

13. ОФС 1.5.3.0010.15 Определение содержания эфирного масла в лекарственном растительном сырье и лекарственных растительных препаратах. Режим доступа http://femb.ru/femb/pharmacopea.php

14. A Review of the Composition of the Essential Oils and Biological Activities of Angelica Species // K. Sowndhararajan, P. Deepa, M. Kim, S. J. Park, S. Kim // Scientia Pharmaceutica. 2017. Vol. 85 (3): 33. doi: 10.3390/scipharm85030033.

15. WHO Monographs on Selected Medicinal Plants. Vol. 2 // World Health Organization Geneva, 2004. P. 25-34.

16. Development of assay method by HPLC-DAD for the quantitative determination of chromones in Saposhnikovia divaricata radices and its validation / B. M. Urbagarova, V. V. Taraskin, E. E. Shul'ts, L. D. Radnaeva // IOP Conference Series: Earth and Environmental Science. 2019. Vol. 320 (1). doi:10.1088/1755-1315/320/1/012056. 
Б. М. Урбагарова, Л. Д. Раднаева, В. В. Тараскин. Компонентный состав эфирного масла Saposhnikova divaricata (turcz.) schischk. Корней

\section{COMPOSITITION OF THE ESSENTIAL OIL \\ OF SAPOSHNIKOVA DIVARICATA (TURCZ.)SCHISCHK. ROOTS}

\section{Bayarma M. Urbagarova}

Lecturer of Pharmacy Department,

Dorzhi Banzarov Buryat State University

36a Oktyabrskaya st., Ulan-Ude, 670002, Russia

\section{Vasilii V. Taraskin}

Candidate of Pharmaceutical Sciences,

Senior Scientific Researcher of the Lab. of Chemistry of Natural systems,

Baikal Institute of Nature Management Siberian branch of

the Russian Academy of Sciences

6, Sakhyanova st, Ulan-Ude, 670047, Russia

Senior Lecturer of Pharmacy Department,

Dorzhi Banzarov Buryat State University

36a Oktyabrskaya st., Ulan-Ude, 670002, Russia

\section{Larisa D. Radnaeva}

Doctor of Chemical Sciences, Professor, Head of Laboratory,

Baikal Institute of Nature Management SB RAS

8, Sakhyanova st, Ulan-Ude, 670047, Russia

Tel.: +7(3012)434997

E-mail: radld@mail.ru

Head of the Department of Pharmacy

Buryat State University named after D. Banzarova

36a Oktyabrskaya st., Ulan-Ude, 670002, Russia

Tel: +7(3012) 445503

E-mail: radld@mail.ru

Essential oil was obtained by steam distillation (method I). Chemical composition of this group of secondary metabolites of Saposhnikovia divaricata roots of Russian and Mongolian flora was studied using gas chromatography-mass spectrometry. Non-specific components were identified, they indicated occurrence of impurity.

Keywords: Saposhnikovia divaricata (Turcz.) Schischk., Apiaceae, essential oil, $\beta$-bisabolene, (Z)-falcarinol, Fang Feng, herbal medicine, medicinal plant raw material. 